\title{
Environmental Risk Assessment of dredging processes - application to Marin harbour (NW Spain)
}

\author{
A. G. Gómez, J. García Alba, A. Puente, and J. A. Juanes \\ Environmental Hydraulics Institute "IH Cantabria", Universidad de Cantabria, Santander, Spain \\ Correspondence to: A. G. Gómez (aina.gomez@unican.com)
}

Received: 14 October 2013 - Revised: 13 December 2013 - Accepted: 16 December 2013 - Published: 1 April 2014

\begin{abstract}
A methodological procedure to estimate the environmental risk of dredging operations in aquatic systems has been developed. Environmental risk estimations are based on numerical models results, which provide an appropriated spatio-temporal framework analysis to guarantee an effective decision-making process. The methodological procedure has been applied on a real dredging operation in the port of Marin (NW Spain). Results from Marin harbour confirmed the suitability of the developed methodology and the conceptual approaches as a comprehensive and practical management tool.
\end{abstract}

\section{Introduction}

Environmental effects on the aquatic environment are mainly due to human activities (EEA, 2006). The implementation of evaluation procedures allows discriminating the origins and effects of different hazards, with the aim to promote an appropriate management (Hope, 2006; Landis, 2003). In that sense, the Environmental Risk Assessment (ERA) associated to dredging processes should allow the evaluation of potential impacts of dredging operations on the environment.

The risk assessment is based on three steps: (i) the identification of hazards, (ii) the risk estimation and evaluation and (iii) the decision making process on an appropriate course of action, in order to manage these risks in a cost-effective manner (Micallef et al., 2001). The first step allows producing a comprehensive list of all the hazards and their characteristics. In the case of dredging processes, hazards should be related to ecological effects on pelagic and benthic communities, predators and human health, following the SPRC conceptual model (Source-Pathway-Receptor-Consequences). Risk estimation $(R)$ involves the description of these ecological effects, in terms of their nature and magnitude, by the assess- ment of the derived consequences from hazard occurrence $(C)$ and the vulnerability of the environment $(V)$ (Labodová, 2004; Salvi and Debray, 2006).

Using numerical model results to estimate the environmental risk would allow interpreting, simulating and predicting responses of aquatic systems to different environmental conditions and dredging characteristics (hydrodynamic currents, type of dredgers, pollutants, etc.) (García et al., 2007). Consequently, these results would be an essential source of information for a successful management of a dredged area.

The aim of the present study is to develop a methodological procedure to assess the environmental risk of dredging in aquatic systems. This methodology is applied to a real dredging operation.

\section{Environmental Risk Assessment of dredging processes}

Environmental Risk Assessment due to dredging operations is considered as combination of two components: vulnerability and consequences. The selection of parameters to estimate each component and definition of a formula to integrate them are set up to assess the environmental risk of any dredging process.

The study area is divided into regular square cells where each parameter is estimated. The cell dimension is a function of the size of the study area, and its resolution depends on the desired detail level (Fig. 1).

Vulnerability is defined as the characteristic of a system that describes its potential to be harmed (Birkmann, 2007). Thus, vulnerability is expressed in terms of functional relations between the environment susceptibility against a disturbance and the state of conservation related to the value of the receptors at risk (Kaly et al., 1999). Susceptibility is 


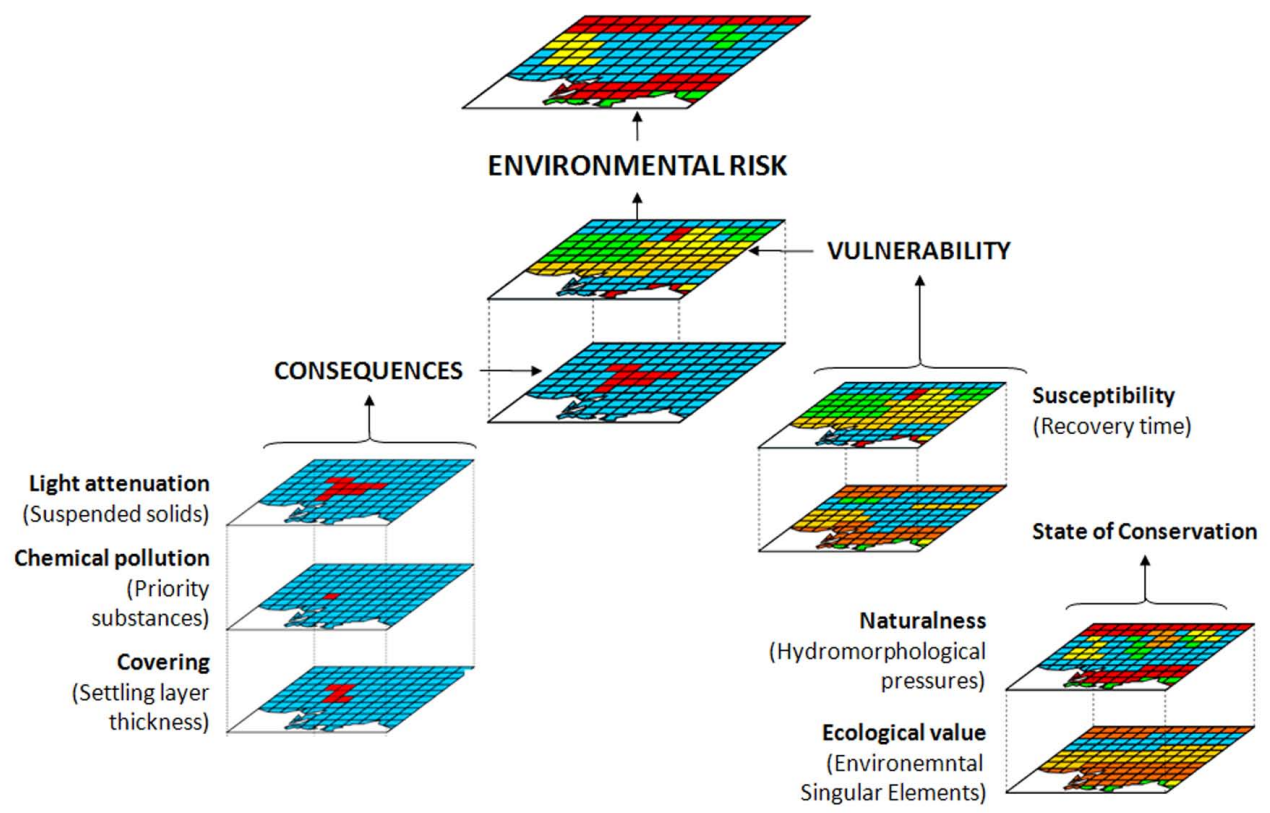

Fig. 1. Pathway for the integration process of indicators to estimate environmental risk.

associated to the flushing capacity of aquatic systems (cleaning capacity). While, the state of conservation of physical, biological and chemical processes and elements of the environment is defined as a combination of: naturalness and ecological value (Gómez, 2010) (Table 1). In order to recognize the importance of each parameter and define their integration, a sensitivity analysis was performed through a participatory process with 16 experts (Eq. 1) (Gómez et al., 2012).

Consequences are defined as the impacts on environment (damage/improvement) that may result from a hazard. Then, consequences on aquatic systems generated by dredging operations are expressed in terms of ecological effects produced by main physical changes: light attenuation (resuspension), burial/covering (sedimentation) and chemical pollution (increased concentration of chemicals) (PIANC, 1997; IH Cantabria, 2013) (Table 1). Consequences assessment is obtained from the integration of different ecological effect estimations using the worst case method (the maximum value obtained). Chemical pollution is computed as the maximum value obtained for any effect (acute, chronic), at any receptor (pelagic community, benthic community, predators and human) by any considered priority substance (Eq. 1).

$$
\begin{aligned}
R_{i, j} & =\overbrace{\left[1 / 3\left(2 \times \mathrm{SU}_{i, j}+2 / 3\left(\mathrm{NA}_{i, j}+2 \times \mathrm{EV}_{i, j}\right)\right)\right]}^{V_{i j}} \\
& \times \overbrace{\left.\left[\mathrm{MAX}_{\operatorname{MAA}} \mathrm{L}_{i, j}, \mathrm{CO}_{i, j}, \mathrm{CP}_{i, j}\right\}\right]}^{C_{i j}}
\end{aligned}
$$

The environmental risk at each cell is classified according the following four categories: Low $\left(R_{i j} \leq 1\right)$, Moderate $\left(1<R_{i j}<4\right)$, High $\left(4 \leq R_{i j}<10\right)$ and, Very High $\left(R_{i j} \geq 10\right)$, obtaining a spatial variation of environmental risk against a dredging process.

\section{Application to Port of Marin}

The environmental risk assessment methodology was applied to a real dredging operation carried out in the Port of Marin, a harbour located in Southern shore of the Ria of Pontevedra (NW Spain) (Fig. 2). The mesh grid consisted of $122 \times 102$ square cells with a cell dimension of $25 \mathrm{~m}$. To assess the corresponding environmental risk, each indicator was calculated in every cell. The hydrodynamic forcing conditions (three dimensional currents, salinity and temperature fields and water levels) were estimated using numerical models. The settling thickness layer, the evolution of suspended solids and the concentration of priority substances were computed with the IH Dredge model. The reader is refereed to Garcia Alba et al. (2013) for a detailed description of the IH Dredge model, the hydrodynamic calibration, the dredging characteristics and results.

To assess susceptibility the recovery time (RT) was computed. The RT ranged from less than 1 day to values over 1000 days. As expected, RT provided a marked spatial variation. Higher values ( $>1$ day, moderate, high and very high susceptibility) were located at confined areas where the water volume is sheltered by port infrastructures from the hydrodynamic currents. Lower values ( $<1$ day, low susceptibility) were found in natural waters, far away from port infrastructures or natural geographical features. Buffer areas of 84 hydromorphological pressures (HPs), identified by aerial photographies, were computed to assess naturalness. HPs were 
Table 1. Definition, indicator, metric and assessment criteria to estimate each parameter in the environmental risk estimation.

\begin{tabular}{|c|c|c|c|c|c|}
\hline \multirow{4}{*}{ Vulnerability $\left(V_{i j}\right)$} & \multirow{2}{*}{$\begin{array}{l}\text { Parameter definition } \\
\text { Susceptibility }\left(\boldsymbol{S} \boldsymbol{U}_{i j}\right) \text {, capacity } \\
\text { of the environment to assimilate } \\
\text { an external influence. }\end{array}$} & \multirow{2}{*}{$\begin{array}{l}\text { Indicator, metric } \\
\text { Recovery time* }\left(\mathrm{RT}_{i j}\right) \text { calcu- } \\
\text { lated by a hypothetical tracer } \\
\text { experiment. }\end{array}$} & \multicolumn{3}{|c|}{ Assessment criteria } \\
\hline & & & $\begin{array}{l}\mathrm{V} \\
\mathrm{H} \\
\mathrm{M} \\
\mathrm{L}\end{array}$ & $\begin{array}{l}4 \\
3 \\
2 \\
1\end{array}$ & $\begin{array}{l}\mathrm{RT}_{i j}>30 \mathrm{~d} \\
7 \mathrm{~d}<\mathrm{RT}_{i j} \leq 30 \mathrm{~d} \\
1 \mathrm{~d}<\mathrm{RT}_{i j} \leq 7 \mathrm{~d} \\
\mathrm{RT}_{i j} \leq 1 \mathrm{~d}\end{array}$ \\
\hline & $\begin{array}{l}\text { Naturalness }\left(N A_{i j}\right) \text {, absence of } \\
\text { physical anthropogenic modifi- } \\
\text { cations. }\end{array}$ & $\begin{array}{l}\text { Alteration by hydromorpho- } \\
\text { logical pressures } * \quad\left(\mathrm{HP}_{i j}\right), \\
\text { computing buffer areas around } \\
\text { each HP. }\end{array}$ & $\begin{array}{l}\mathrm{V} \\
\mathrm{L}\end{array}$ & $\begin{array}{l}2 \\
1\end{array}$ & $\begin{array}{l}\text { Not altered by HP } \\
\text { Altered by HP }\end{array}$ \\
\hline & $\begin{array}{l}\text { Ecological value }\left(\boldsymbol{E} V_{i j}\right) \text {, ca- } \\
\text { pacity building of a certain area } \\
\text { for supporting species of flora } \\
\text { and fauna. }\end{array}$ & $\begin{array}{l}\text { Ecological singular elements } \\
\left(\mathrm{ESE}_{i j}\right) \text {, by recognizing: local, } \\
\text { regional, national and interna- } \\
\text { tional protected areas (Gómez, } \\
\text { 2010; Gómez et al., 2012). }\end{array}$ & $\begin{array}{l}\mathrm{V} \\
\mathrm{L}\end{array}$ & $\begin{array}{l}2 \\
1\end{array}$ & $\begin{array}{l}\text { Presence of ESE } \\
\text { Absence of ESE }\end{array}$ \\
\hline \multirow[t]{4}{*}{ Consequences $\left(C_{i j}\right)$} & $\begin{array}{l}\text { Light attenuation }\left(\boldsymbol{L A} \boldsymbol{A}_{i j}\right) \text {, re- } \\
\text { duction of light penetration due } \\
\text { to increased turbidity generated } \\
\text { by re-suspension of sediments } \\
\text { into water column. }\end{array}$ & $\begin{array}{l}\text { Average suspended solids con- } \\
\text { centration }\left([\mathrm{SS}]_{i j}\right) \text {, in the wa- } \\
\text { ter column, during the dredging } \\
\text { process using numerical models } \\
\text { (García Alba et al., } 2014 \text { ) }\end{array}$ & $\begin{array}{l}\mathrm{V} \\
\mathrm{H} \\
\mathrm{M} \\
\mathrm{L}\end{array}$ & $\begin{array}{l}4 \\
3 \\
2 \\
1\end{array}$ & $\begin{array}{l}{[\mathrm{SS}]_{i j} \geq 150 \mathrm{mg} \mathrm{L}^{-1}} \\
50 \mathrm{mg} \mathrm{L}^{-1} \leq[\mathrm{SS}]_{i j} \\
<150 \mathrm{mg} \mathrm{L}^{-1} \\
10 \mathrm{mg} \mathrm{L}^{-1} \leq[\mathrm{SS}]_{i j} \\
<50 \mathrm{mg} \mathrm{L}^{-1} \\
{[\mathrm{SS}]_{i j}<10 \mathrm{mg} \mathrm{L}^{-1}}\end{array}$ \\
\hline & $\begin{array}{l}\text { Covering }\left(\mathrm{CO}_{i j}\right) \text {, smothering } \\
\text { of biota and alteration of ben- } \\
\text { thic habitat due to sedimenta- } \\
\text { tion induced by dredging activ- } \\
\text { ities. }\end{array}$ & $\begin{array}{l}\text { Settling layer thickness }\left(\Delta Z_{i j}\right) \\
\text { over bottom during the dredg- } \\
\text { ing process using numerical } \\
\text { models (García Alba et al., } \\
\text { 2014). }\end{array}$ & $\begin{array}{l}\mathrm{V} \\
\mathrm{H} \\
\mathrm{M} \\
\mathrm{L}\end{array}$ & $\begin{array}{l}4 \\
3 \\
2 \\
1\end{array}$ & $\begin{array}{l}\Delta Z_{i j} \geq 5 \mathrm{~cm} \\
2 \mathrm{~cm} \leq \Delta Z_{i j}<5 \mathrm{~cm} \\
1 \mathrm{~cm} \leq \Delta Z_{i j}<2 \mathrm{~cm} \\
\Delta Z_{i j}<1 \mathrm{~cm}\end{array}$ \\
\hline & $\begin{array}{l}\text { Chemical pollution }\left(\mathrm{CP}_{i j}\right) \text {, } \\
\text { physiological responses to } \\
\text { contaminants in pelagic and } \\
\text { benthic communities, predators } \\
\text { and humans by priority sub- } \\
\text { stances in dredged sediments } \\
\text { (Directive } 2008 / 105 / \mathrm{CE}) \text {. }\end{array}$ & $\begin{array}{l}\text { Acute effects* }\left(\%_{i j}\right) \text {, as the } \\
\text { MAC-EQS non-fulfillment } \\
\text { time percentage in water col- } \\
\text { umn by each priority substance, } \\
\text { during the dredging operation. }\end{array}$ & $\begin{array}{l}\mathrm{V} \\
\mathrm{H} \\
\mathrm{M} \\
\mathrm{L}\end{array}$ & $\begin{array}{l}4 \\
3 \\
2 \\
1\end{array}$ & $\begin{array}{l}\%_{i j} \geq 3.0 \\
1.0 \leq \%_{i j}<3.0 \\
0.1 \leq \%_{i j}<1.0 \\
\%_{i j}<0.1\end{array}$ \\
\hline & & $\begin{array}{l}\text { Chronic effects* }\left(\mathrm{HQ}_{i j}\right) \text {, by } \\
\text { comparing the average concen- } \\
\text { tration (in water or sediments) } \\
\text { of each priority substance to } \\
\text { AA-EQS, during the dredging } \\
\text { operation. }\end{array}$ & $\begin{array}{l}\mathrm{V} \\
\mathrm{H} \\
\mathrm{M} \\
\mathrm{L}\end{array}$ & $\begin{array}{l}4 \\
3 \\
2 \\
1\end{array}$ & $\begin{array}{l}\mathrm{HQ}_{i j} \geq 100 \\
30 \leq \mathrm{HQ}_{i j}<100 \\
1 \leq \mathrm{HQ}_{i j}<30 \\
\mathrm{HQ}_{i j}<1\end{array}$ \\
\hline
\end{tabular}

* See Appendix A for more details.

V: Very high; H: High; M: Moderate; L: Low.

MAC-EQS: Maximum Allowable Concentration-Environmental Quality Standards in water.

AA-EQS: Annual Average-Environmental Quality Standards in water and sediments established to protect pelagic community, benthic community, predators and humans.

mainly located around the harbour area, resulting of low naturalness. Finally, there were identified some protected sites corresponding to bathing waters, sensitive areas, and shellfishing areas, providing a very high ecological value for all cells.

The effects on light attenuation and covering, due to the increasing of suspended solids concentration and sedimentation, were mainly located in small areas inside the dredging area, showing moderate effects. Chemical pollution pre- sented an extensive area of moderate risk, due to chronic effects on the pelagic community with HQ values between 1 and 30 .

Finally, spatial environmental risk assessment provided a moderate risk for the entire study area with the exception of internal harbour areas presenting high risk (Fig. 3). From these results it is seen that confined areas presented affection by chemical pollution and, in addition, their susceptibility was low due to insufficient flushing capacity. In that 


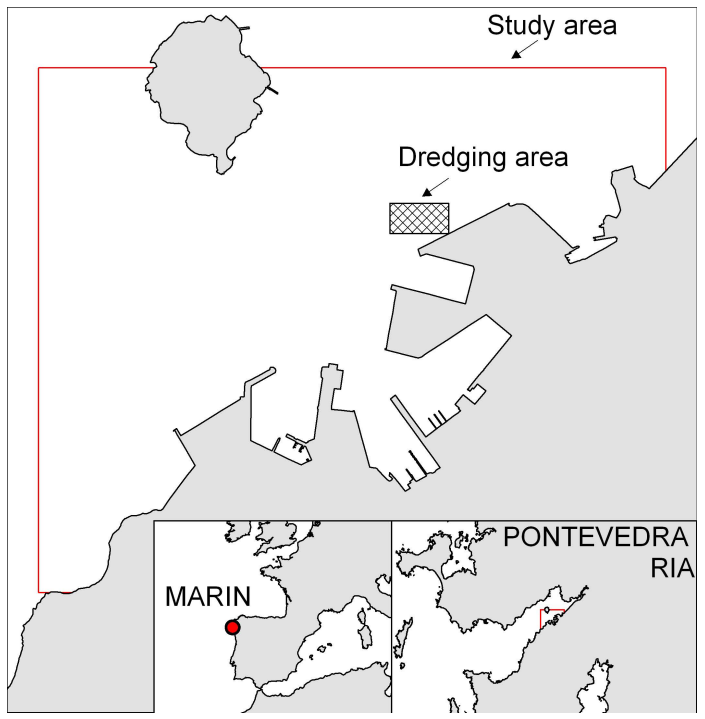

Fig. 2. Location of the Port of Marin and the dredging area.

sense, the use of preventive measures (turbidity curtains) during dredging operation would reduce the dispersion of suspended solids and chemicals. This fact would considerably decrease the value of environmental risk in the inner areas of the harbour.

\section{Conclusions}

Bearing in mind the goal of this paper, we can conclude that the methodological procedure to estimate environmental risk for dredging processes constitutes an advanced, precise and detailed procedure, being suitable for the management of this type of activities. The use of numerical models allows to consider various scenarios and to obtain spatial and temporal patterns of different indicators. This methodology provides information both on ecological effects and environment characteristics, essential data for a cost-benefit management. The methodology has been applied to a real dredging operation developed at the Port of Marin (Spain), confirming the usefulness of this coherent tool.

\section{Appendix A}

\section{Indicators calculation}

All indicator calculations are carried out on the study area through a mesh grid of square regular cells. Recovery time, average suspended solids concentration, settling layer thickness, acute and chronic effects of chemical pollution are computed using numerical models. Alteration of hydromorphological pressures and ecological singular elements are obtained using Geographical Information Systems (GIS). All results are integrated (Eq. 1) at a cell level to estimate spa-

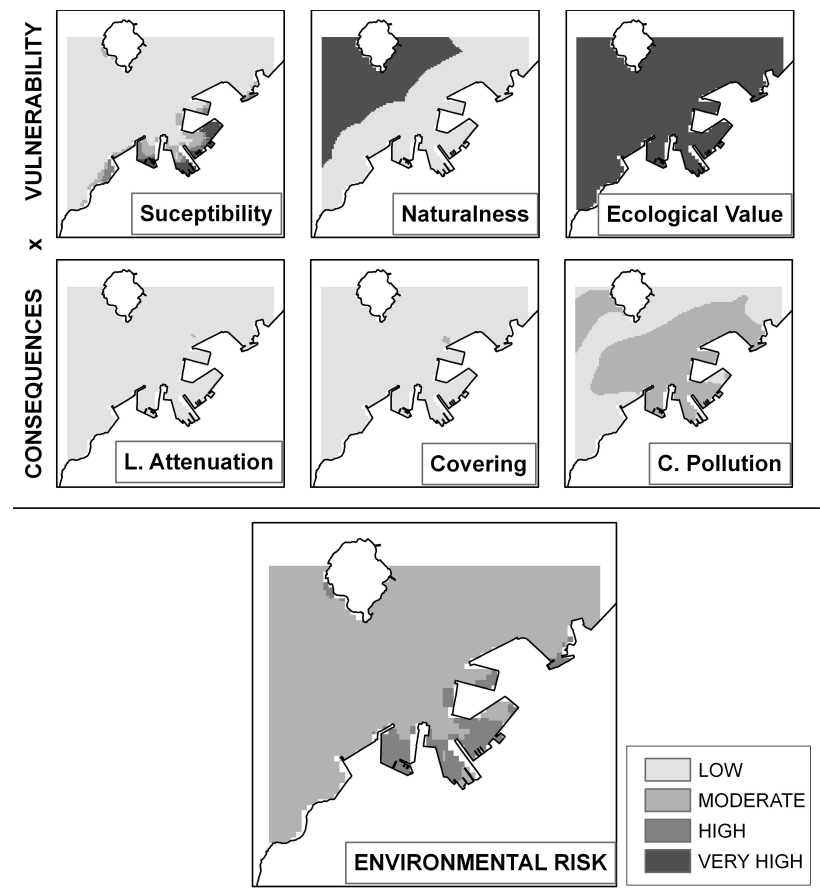

Fig. 3. Assessment of environmental risk parameters in a real dredging operation in the Port of Marin (SW Spain).

tially the environmental risk in the whole domain. Following, there are required details on the calculation process of some of these indicators.

Recovery time (RT): RT is defined as the time needed to completely flush the water volume of a cell. RT is calculated with regard to a hypothetical tracer experiment by means of depth average numerical models (2-D). A tracer concentration is released inside a cell, being zero elsewhere. The concentration of the tracer in the cell decreases as advection and dispersion act. RT is computed as the time required to reduce the concentration in the cell to a $0.1 \%$, considering annual average hydrodynamic forcings (Gómez et al., 2007;Gómez, 2010).

Alteration by hydromorphological pressures (HP): naturalness is calculated obtaining buffer areas around each HP using buffer tools in GIS. Buffer distance of a HP is:

$d=k \times(L / \mathrm{CV})^{2}$

where $k$ equals 1 if the HP is continuous (dike, wharf), $k$ equals 0.5 if the HP is discontinuous (bridge, jetty); $L$ is the length of the pressure; and $\mathrm{CV}$ is the critical value, defined as the length at the HP that is considered significant. $\mathrm{CV}$ equals $50 \mathrm{~m}$ for channeling dikes, detached breakwaters, breakwaters; $100 \mathrm{~m}$ for canalizations, main breakwater, piers, quays, wharfs, jetties, margin protection, and; $150 \mathrm{~m}$ for shoreline structures (wall, pre-formed concrete blocks, sheet piles) (Ministerial Order ARM/2656/2008). Buffer areas of 
all identified HP are considered altered areas and present low naturalness (Gómez, 2010).

Acute effects (\%): all priority substances (Directive 2008/105/CE) present in the dredged sediments have the potential to affect the pelagic community in a short space of time. Other receptors, as benthic community, cannot be affected by acute effects. Acute effects of each priority substance in every cell are computed by the percentage of time in adverse conditions:

$\%_{i j}=\frac{t_{\text {adverse_conditions, } j}}{t_{\text {total }}} \times 100$

where $t_{\text {adverse_conditions }}$ is the time at which it exceeds MACEQS (Maximum Allowable Concentration-Environmental Quality Standards, Directive 2008/105/EC), and $t_{\text {total }}$ is the time of dredging operation (Gómez, 2010).

Chronic effects $(H Q)$ : pelagic community can be affected by long-term exposures of any priority substances present in the dredged sediments. Hydrophobic priority substances (partition coefficient $\geq 3$ ) have the potential to affect benthic community, while predators may be affected if the substance can bioaccumulate (Bioconcentration factor $\geq 100$, Biomagnification factor $\geq 1$, or for organic substances octanol-water partition coefficient $\geq 3$ ). Finally, carcinogen or mutagen priority substances, or with potential to affect reproduction or to bioaccumulate can affect humans. Chronic effects of each priority substance in every cell, considering each receptor, are computed using the quotient method:

$\mathrm{HQ}_{i j}=\overline{\left[X_{i j}\right]} / \mathrm{AA}-\mathrm{EQS}$

where $\overline{\left[X_{i j}\right]}$ is the average concentration of a priority substance during the dredging process, and AA-EQS is the Annual Averaged-Environmental Quality Standard (Gómez, 2010; EPA, 1992). AA-EQS for pelagic community are collected in the European Directive 2008/105/CE in terms of water concentration $\left(\mu \mathrm{g} \mathrm{L}^{-1}\right)$. AA-EQS for benthic community in terms of sediment concentration $\left(\mu \mathrm{g} \mathrm{kg}^{-1}\right.$ wet weight) and, AA-EQS for predators and human transformed to concentrations in water $\left(\mu \mathrm{g} \mathrm{L}^{-1}\right)$ are collected in several technical reports (CIRCA, 2005, 2009; Lepper, 2005).

Acknowledgements. The authors would like to thank the Marin Port Authority for the provided data. Part of this study has been sponsored by the INNPACTO programme (2008-2011) of the Spanish Ministry of Science and Innovation (IPT-310000-2100-17).

\section{References}

Birkmann, J.: Risk and vulnerability indicators at different scales:: Applicability, usefulness and policy implications, Environ. Hazards, 7, 20-31, 2007.

CIRCA: Priority substance; No. 1 Alachlor; No. 2 Anthracene; No. 3 Antrazine; No. 4 Benzene; No. 5a Diphenylether, pentabromo derivative (pentabromodiphenylether); No. 5b Diphenylether, octabromo derivative (octabromodiphenylether)No. 6 Cadmium and its compounds; No. 7 C10-13-Choloalkanes; No. 8 Chlorfenvinphos; No. 9 Chlorpyrifos; No. 10 1,2-Dichloroethane; No. 11 Dichloromethane; No. 12 Diethylheylphthalate (DEHP); No. 13 Diuron; No. 14 Endosulfan; No. 15 Fluoranthene; No. 16 Hexachlorobenzene; No. 17 Hexachlorobutadiene; No. 18 Hexachlorocyclohexane; No. 19 Isoproturon; No. 20 Lead and its Compounds; No. 21 Mercury and its Compounds; No. 22 Naphtalene; No. 23 Nickel and its compounds; No. 24 4-Nonylphenol (branched) and Nonylphenol; No. 25 Octylphenols; No. 26 Pentachlorobenzene; No. 27 Pentachlorophenol; No. 28 Polyaromatic Hydrocarbons (PAHs); No. 29 Simazine; No. 30 Tributyltin compounds (TBT-ion); No. 31 Trichlorobenzenes; No. 32 Trichloromethane; No. 33 Trifluralin. Environmental Quality Standards. Substance Data Sheet, SCTEE, Bruselas, 13, 2005.

CIRCA: Prioritisation process: Final monitoring-based ranking, Annex VII: PNEC values and hazard information for candidate substances, 2009.

EEA: The changing faces of Europe's coastal areas, European Environmental Agency, Copenhagen, 112, 2006.

EPA: Framework for ecological risk assessment. Risk Assessment Forum, U.S. Environmental Protection Agency, EPA/630/R92/001, Washington D.C., 57, 1992.

García, A., Fernández, F., Gómez, G. A., García, J., Revilla, J. A., Álvarez, C., and Juanes, J. A.: A methodological approach to integrate a water quality numerical model into a geographical information system., Proceedings 8th International Symposium on GIS and Computer Mapping for Coastal Zone Management. COASTGIS07, Santander - Cantabria, Vol. 2, 434-443, ISBN: 978-84-8102-471-5, 2007,

García Alba, A., Gómez, A. G., Tinoco López, R. O., Sámano Celorio, M. L., García Gómez,A., and Juanes, J. A.: A 3-D model to analyze environmental effects of dredging operations - application to the Port of Marin, Spain. Adv, Geosci,, 1, 1-5, 2014.

Gómez, A. G., Ondiviela, B., Juanes, J. A., Revilla, J. A., García, A., Vargas, A., Álvarez, C., and Puente, A.: A risk assessment approach to contaminant emissions in seaport areas: methodological procedure to calculate susceptibility, Forth International Conference on Port Development and Coastal Environment, Varna, Bulgaria, 2007.

Gómez, A. G.: Desarrollo de un procedimiento metodológico para la estimación del riesgo ambiental en zonas litorales frente a emisiones contaminantes, Departamento de Ciencias y Técnicas del Agua y del Medio Ambiente, Doctoral Thesis, Universidad de Cantabria, Santander, 2010.

Gómez, A. G., Garmendi, J., Loureiro, S., Bebiano, M., Knowles, H., and Lupson, K.: Environmental Risk Assessment Activity. Technical Report \#2, PORTONOVO Project: Water quality in harbours. INTERREG IVB, Atlantic Area Programme, Ref:2009-1/119, 2012.

Hope, B. K.: An examination of ecological risk assessment and management practices, Environ. Int., 32, 983-995, 2006. 
IH Cantabria: Desarrollo de herramientas predictivas para la estimación de efectos ambientales, Procedimientos metodológicos cuantitativos para el análisis del riesgo ambiental en procesos de dragado, INNODRAVAL project (IPT-310000-2100-17), 2013.

Kaly, U. L., Briguglio, L., McLeod, H., Schmall, S., Pratt, C., and Pal, R.: Environmental Vulnerability Index (EVI) to summarise national environmtenal vulnerabiilty profiles. SOPAC, South $\mathrm{Pa}-$ cific Applied Geoscience Commission, 66, 1999.

Labodová, A.: Implementing integrated management systems using a risk analysis based approach, Journal of Cleaner Production, 12, 571-580, 2004.

Landis, W. G.: The frontiers in ecological risk assessment at expanding spatial and temporal scales, Human and Ecological Risk Assessment, 9, 1415-1424, 2003.

Lepper, P.: Manual on the Methodological Framework to Derive Environmental Quality Standards for Priority Substances in accordance with Article 16 of the Water Framework Directive (2000/60/EC), Fraunhofer-Institute Molecular Biology and Applied Ecology, Shmallenberg, 47, 2005.
Micallef, A., Williams, A. T., and Cassar, M.: Environmental Risk Assessment: Application to a proposed beach nouirshment, Malta, shore and Beach, 69, 13-17, 2001.

Ministerial Order ARM/2656/2008: de 10 de septiembre, por la que se aprueba la instrucción de planificación hidrológica, 2008.

PIANC: Dredged Material Management Guide, Special Report of the Permanent Environmental Commission, Supplement to Bulletin n-96, 1997.

Salvi, O. and Debray, B.: A global view on ARAMIS, a risk assessment methodology for industries in the framework of the SEVESO II directive, Journal of Hazardous Materials, 130, 187 199, 2006. 